
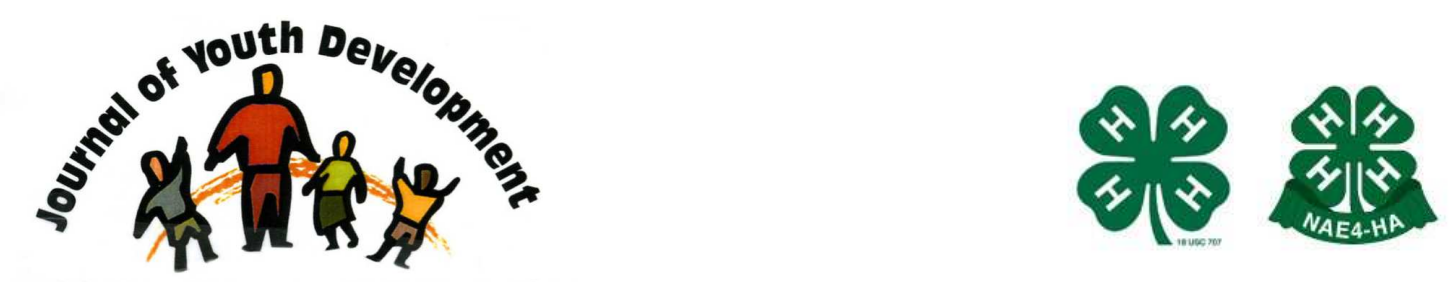

Bridging Research \& Practice

\title{
Science Saturdays: A Ground Up Approach to Partnering with Content-Rich Corporate Volunteers
}

\author{
Chad Ripberger \\ Rutgers Cooperative Extension of Mercer County \\ Trenton, New Jersey \\ ripberger@njaes.rutgers.edu
}

Lydia B. Blalock

Rutgers Cooperative Extension of Mercer County

Trenton, New Jersey 


\title{
JOURNAL OF YOUTH DEVELOPMENT \\ bridging research and practice

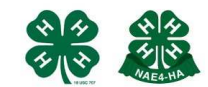

Volume 10, Number 2, Summer 2015

Article 151002PA001

\section{Science Saturdays: \\ A Ground Up Approach to Partnering with Content-Rich Corporate Volunteers}

\author{
Chad Ripberger and Lydia B. Blalock \\ Rutgers Cooperative Extension of Mercer County
}

\begin{abstract}
This article discusses the pilot year of a 4-H Science project in which Mercer County 4-H partnered with content-rich corporate volunteers of a global STEM corporation to plan and implement six Science Saturdays for $4^{\text {th }}-7^{\text {th }}$ grade youth from Trenton and surrounding urban neighborhoods. The program was a ground up initiative designed and implemented by a core group (mostly women), which expanded to include 31 corporate volunteers by the end of the pilot year (2013-2014). The Science Saturdays were held once a month with each session focused on a different theme and included demonstrations or experiments along with other supporting activities. While all four program goals were met during the pilot year, results from the 4-H Science Common Measures survey did not reveal significant increases or improvements in youth outcome objectives. Findings and implications are discussed, as well as current and future programming.
\end{abstract}

\section{Introduction}

There is a growing appreciation for and focus on the role out-of-school time (OST) programs play in preparing young people for a world increasingly reliant on science, technology, engineering, and mathematics (STEM). While many efforts to improve STEM education in America over the past couple of decades have focused on the formal education sector, there is increased interest in looking at the total learning system and the contributions made by afterschool and summer program providers, science centers, youth development organizations, and others in the OST field (National Research Council, 2014). The Afterschool Alliance (2013) recently completed a study to develop consensus around STEM learning outcomes most appropriate for afterschool. The study identified outcomes related to youth interest and engagement in STEM activities, knowledge and abilities in STEM processes and life and career skills, and awareness of STEM careers and understanding of STEM contributions to society. These targeted outcomes are consistent with the goals of the 4-H Science program (4-H Science Management Team, 2010). At the same time, many STEM corporations have similar goals, as they work to develop a larger base of highly skilled and diverse employees. These 
corporations are interested in finding ways for their employees to volunteer in the STEM programs they fund. Not only do the corporations want to financially support these programs, they are interested in mentoring the next generation of scientists and engineers, especially those groups underrepresented in STEM fields (STEMconnector, 2014).

The OST field and the 4-H Science program recognize the potential value of engaging these corporate employees in their STEM programming (Afterschool Alliance, 2013; Ripberger, \& Blalock, revised 2013). In an effort to involve content-rich volunteers, many 4-H professionals are developing innovative partnerships that challenge traditional volunteer recruitment and program delivery methods (Barker, Grandgenett, \& Nugent, 2009; Riley, \& Butler, 2012).

The purpose of this article is to describe how Mercer County (New Jersey) 4-H partnered with local employees of a global STEM corporation to design and implement a pilot OST science program for youth from populations typically underrepresented in STEM fields.

\section{Program Design}

\section{Program Description}

Mercer County 4-H partnered with 31 content-rich corporate volunteers from the Women's Resource Group of a local facility of a global STEM corporation to plan and implement shortterm, quality, out-of-school STEM programming for underrepresented youth in Trenton, New Jersey and surrounding urban neighborhoods. The result was "Science Saturdays," which were held once a month from October 2013 to April 2014, from 9:30 a.m. to 12:00 p.m. at Rutgers Cooperative Extension of Mercer County. Youth were strongly encouraged to attend all six Saturdays.

An executive from the STEM corporation started each Science Saturday with a review of the prior Saturday and an introduction to the current topic, which included an explanation about how the activity fit in with the corporation's current, real-world research. The executives often remained and participated in the session. Each Saturday focused on a different theme and included two primary demonstrations or experiments along with other supporting activities. First year activities included DNA extraction and modeling, ice cream and cheese production, bridge construction using spaghetti, and how diseases spread in communities. On the fourth session, the youth learned about science investigations in advance of conducting their own experiments in small teams during the fifth Saturday. In April, each team presented their "Science Fair" project to a crowd of participants, volunteers, parents, and funders. Activities were facilitated by teams of corporate volunteers, and included projects designed to develop specific life skills (teamwork, communications, problem-solving, etc.) in addition to the targeted science practices.

\section{Content-Rich Corporate Volunteers}

The 4-H/STEM corporation partnership was initiated and implemented using a "ground up" (as opposed to "top down") approach. A current 4-H volunteer approached the Mercer County, New Jersey 4-H Agent about partnering with her STEM company to deliver short-term STEM programming. The volunteer, a member of the Women's Resource Group at her corporation, invited some of her colleagues to meet with the agent to discuss possible program development. This group later evolved into the program's steering committee. A core team of 30 volunteers was recruited for the initial site using the company's internal resources. The scientists determined that Saturday mornings would be the best time for their program, and they worked together to develop ideas and lesson plans for six Science Saturday projects. 
Program responsibilities were divided between the 4-H agent and the STEM volunteers. The 4-H agent was responsible for recruiting youth participants, marketing, enrollment, program evaluation, reporting, etc., and for supporting the volunteers on Science Saturdays. Volunteers were responsible for creating and delivering the activities and acquiring all materials, which were reimbursed by the corporation. It is important to note that no monetary funds were exchanged between the corporation and $4-\mathrm{H}$.

\section{Program Goals}

The goals of the program in year one (2013-2014) were:

1. Six Science Saturdays will be implemented in Trenton, New Jersey.

2. The majority of youth participants will be from groups underrepresented in STEM college majors and careers (girls and racial minorities).

3. The program will serve a minimum of 50 youth.

4. At least 30 STEM corporation employees will be engaged in planning and implementing the program.

\section{Youth Outcome Objectives}

The youth outcome objectives in year one (2013-2014) were:

1. Youth will demonstrate an increased interest and engagement in STEM.

2. Youth will demonstrate improved attitudes and aspirations toward STEM.

3. Youth will develop STEM skills and abilities.

\section{Project Evaluation}

\section{Methods}

The overall program outcomes were evaluated using enrollment data and session sign-in sheets. The 4-H enrollment forms requested demographic information. These enrollment forms were used to determine the percent of underrepresented youth. Parents signed their children in and out before and after each Science Saturday. These sign-in sheets were used to track overall attendance and retention of youth participants. A similar process was used to track the number of STEM corporation volunteers involved in the project.

To evaluate progress toward youth outcomes, the $4^{\text {th }}-7^{\text {th }}$ grade version of the 4-H Science Common Measures Survey (4-H Science Evaluation Team, 2012) was administered prior to the first session (October $n=46$ ) and at the end of the final session (April $n=32$ ). The survey is a 4point Likert scale (4=strongly agree; $1=$ strongly disagree) designed to determine changes in interest and engagement and attitudes and aspirations toward science, as well as the development of basic skills in science. Youth were also asked two open-ended format questions to determine program appeal and effectiveness.

\section{Results}

\section{Program Goals}

All four program goals were met for the pilot year (2013-1014). Six Science Saturdays were held between October 2013 and April 2014 in Trenton, New Jersey. The majority of youth participants were from groups underrepresented in STEM college majors and careers (girls and racial minorities). The program served 63 individual youth. A total of 31 STEM corporation employees were engaged in planning and implementing the program. 


\section{Youth Outcome Objectives}

Youth will demonstrate an increased interest and engagement in STEM. Youth were asked to rate their responses to several items using a 4-point scale (see Table 1).

\section{Table 1}

Interest and Engagement in STEM

$4=$ strongly agree; $1=$ strongly disagree

\begin{tabular}{|l|r|r|}
\hline \multicolumn{1}{|c|}{ Item } & Pre (n=46) & Post $(\mathbf{n = 3 2 )}$ \\
\hline I get excited about new discoveries & 3.39 & 3.55 \\
\hline I like to see how things are made or invented & 3.48 & 3.48 \\
\hline I like experimenting and testing ideas & 3.65 & 3.31 \\
\hline I want to learn more about science & 3.54 & 3.38 \\
\hline
\end{tabular}

2. Youth will demonstrate improved attitudes and aspirations toward STEM. Youth were asked to rate their responses to several items using a 4-point scale (see Table 2).

Table 2

Attitudes and Aspirations Toward STEM

$4=$ strongly agree; $1=$ strongly disagree

\begin{tabular}{|l|r|r|}
\hline \multicolumn{1}{|c|}{ Item } & Pre (n=46) & Post $(\mathbf{n = 3 2 )}$ \\
\hline I am good at science & 3.11 & 3.16 \\
\hline I do science activities that are not for school & 2.65 & 2.84 \\
\hline I like science & 3.48 & 3.40 \\
\hline I would like to have a job related to science & 2.80 & 2.75 \\
\hline
\end{tabular}

3. Youth will develop STEM skills and abilities. Youth were asked to answer yes (1) or no (0) to several items (see Table 3).

Table 3

Develop STEM Skills and Abilities

$1=$ yes; $0=$ no

\begin{tabular}{|l|r|r|}
\hline \multicolumn{1}{|c|}{ Item } & Pre $(\mathbf{n = 4 6 )}$ & Post $(\mathbf{n = 3 2 )}$ \\
\hline I can explain why things happen in an experiment & 0.67 & 0.84 \\
\hline I can tell others how to do an experiment & 0.65 & 0.74 \\
\hline I can do an experiment to answer a question & 0.87 & 0.90 \\
\hline
\end{tabular}

\section{Program Appeal and Effectiveness}

Youth $(n=32)$ were also asked two open-ended questions as part of the post-program survey. The first asked youth to describe the two most valuable things they had learned (see Table 4). The second question asked participants to list what they liked about the program (see Table 5). 
Table 4

Describe the two most valuable things you learned/gained from this program.

\begin{tabular}{|l|r|}
\hline Response & Count \\
\hline Learned more about science, including DNA (11), bridge building (4) & 34 \\
\hline Making ice cream & 7 \\
\hline How to carry out and document experiments & 5 \\
\hline How to work together & 4 \\
\hline Making cheese & 3 \\
\hline Making models out of household things & 2 \\
\hline Science is important & 2 \\
\hline If you try your best you will succeed & 1 \\
\hline & Total \\
\hline
\end{tabular}

Table 5

Explain what you liked about this program.

\begin{tabular}{|l|r|}
\hline Response & Count \\
\hline Experiments facilitated by the volunteers & 23 \\
\hline Volunteers were helpful, nice, kind & 12 \\
\hline It taught me more about science & 9 \\
\hline Working together, making new friends & 8 \\
\hline Science is fun! & 8 \\
\hline Snacks & 4 \\
\hline Inventing & 1 \\
\hline & Total \\
\hline
\end{tabular}

\section{Discussion}

\section{The Program}

\section{Youth Outcome Objectives}

Results from the 4-H Science Common Measures Survey did not reveal significant increases or improvements in the items measured. There are two important explanations for these findings. First, youth self-selected into the program, which was held on Saturdays. These youth already had fairly high levels of interest in and aspirations toward science (see pre-survey results), so much so that they elected to spend part of their weekend engaged in a science program! Second, as explained under program goals, not all youth attended all sessions, and youth who completed the pre-survey may not have been the same youth who completed the post-survey. This is a problem that many such programs face regarding the need to document results. Does that mean the program did not benefit the youth involved? No. That over half the participants attended at least $75 \%$ of the sessions indicates the youth benefitted in ways the 4-H Science Common Measures Survey did not capture.

The responses to the open-ended questions provide a little insight into those benefits. The first asked youth to describe the two most valuable things they had learned. Thirty-four responses related to specific science content information, while others were about how to do experiments $(n=5)$, how to work together $(n=4)$, and the importance of science. When asked to list what they liked about the program, 23 responses were related to doing the experiments and 12 were about the helpful, nice, and kind volunteers. Perhaps the value of this program was not so 
much in "increasing" or "improving" science skills, abilities, and aspirations in youth who already had an interest in science, but in solidifying those traits while layering positive STEM experiences that included contact with STEM corporate professionals.

The authors believe these ideas warrant more discussion among youth development program professionals, particularly those engaged in STEM programming. Does "layering" increase longterm movement toward STEM careers? If a STEM program attracts youth with high levels of interest, aspirations, and skills, has the program "failed" if statistically significant gains are not realized? Is a more qualitative approach needed to tease out program success? The authors recognize this is not always feasible due to resource constraints.

\section{Content-Rich Partners}

The immediate value of the STEM corporate volunteers was in program planning and implementation. In addition, allowing youth the opportunity to directly interact with STEM professionals allowed them to see scientists as everyday people. When youth participants were asked to explain what they liked about the program, 35 responses specifically addressed the value of content-rich partners. Not only did the volunteers create engaging activities, they also interacted with youth in a helpful, nice, and kind, manner. These responses challenge conventional wisdom that STEM activities require youth development personnel to buffer interactions between content-rich volunteers and youth participants. As one participant stated, "I like this program because the volunteers, and the owners of the program are very helpful to me, and they make sure I know what I have to do." One of the limitations of the current program evaluation is that a volunteer component was not included. This will be addressed in the future in order to help inform current and future efforts to recruit and retain content-rich volunteers.

\section{Why the Program Promises to Be Successful}

Science Saturdays were well attended and well received by the youth participants. Even though the youth had fairly high levels of interest and aspirations coming into the sessions, they came back because the activities were interesting and engaging. Building in time and support for youth to complete Science Fair projects was also a key ingredient of the program.

Underrepresented groups often do not have support for completing personal science projects in their home communities. Some of the youth even went on to present their projects in school.

One of the reasons the 4-H/STEM corporate volunteers partnership worked so well is that this effort was a bottom-up (from the corporate employees) approach. While corporations want to see this kind of collaboration, the implementation may fall short. In this case, beginning with employees who were interested in this type of short-term programming may have been the key to a successful partnership. In addition, internal communications within the company helped spread the word and build excitement about the program. The volunteers developed a comfort level with the program, and have branched out to three locations for the second year (20142015).

\section{Current and Future Directions}

The program was expanded for the second year (2014-2015) to include two new sites in New Brunswick, New Jersey and New Haven, Connecticut. These sites are home to facilities of the same STEM corporation. The two new sites are implementing activities from Year 1, while the volunteers at the Trenton, New Jersey site are piloting new activities. There is a concerted effort to make more explicit links to careers. For example, volunteers talk about their jobs 
during each session. The partnership applied for and received a $\$ 25,000$ grant from the STEM corporation to cover materials, with a small amount allocated to administrative costs for three sites.

Future plans include building upon the current success by exploring the possibility of tapping into medical science liaisons for the same STEM corporation located across the country to host one day events. The partnership is currently in discussions with STEM volunteers and 4-H professionals in San Francisco, California and Tampa, Florida.

\section{References}

4-H Science Evaluation Team. (2012). 4-H science common measures. Retrieved from http://www.4-h.org/commonmeasures/

4-H Science Management Team. (2010). 4-H science logic model. Retrieved from http://www.4h.org/resource-library/professional-development-learning/science-training-guides-resources/

Afterschool Alliance. (2013). Defining youth outcomes for STEM learning in afterschool. Retrieved from http://www.afterschoolalliance.org/STEM Outcomes 2013.pdf

Afterschool Alliance. (2013). Partnerships with STEM-rich institutions. Retrieved from http://www.afterschoolalliance.org/issue 61 STEM.cfm

Barker, B., Grandgenett, N., \& Nugent, G. (2009). A new model of 4-H volunteer development in science, engineering, and technology programs. Journal of Extension, $4 \pi 2$ ). Retrieved from http://www.joe.org/joe/2009april/iw4.php

National Research Council. (2014). STEM learning is everywhere: Summary of a convocation on building learning systems. S. Olson and J. Labov, Rapporteurs. Planning Committee on STEM Learning Is Everywhere: Engaging Schools and Empowering Teachers to Integrate Formal, Informal, and Afterschool Education to Enhance Teaching and Learning in Grades K-8, Teacher Advisory Council, Division of Behavioral and Social Sciences and Education. Washington, DC: The National Academies Press.

Riley, D., \& Butler, A. (2012). Priming the pipeline: Lessons from promising 4-H science programs. Retrieved from http://www.ca4h.org/files/154449.pdf

Ripberger, C., \& Blalock, L.B. (revised 2013). Staffing with content rich volunteers. In 4-H Science in urban communities promising practices guide (pp. 80-85). Retrieved from http://urban4hscience.rutgers.edu

STEMconnector. (2014). Million Women Mentors [Website]. Retrieved from http://www.millionwomenmentors.org/

(C) Copyright of Journal of Youth Development Bridging Research and Practice. Content may not be copied or emailed to multiple sites or posted to a listserv without copyright holder's express written permission. Contact Editor at: patricia.dawson@oregonstate.edu for details. However, users may print, download or email articles for individual use.

ISSN 2325-4009 (Print); ISSN 2325-4017 (Online) 